\title{
Analysis of in vitro activity of PSCA-spe- cific CARs in the context of human NK cell line YT
}

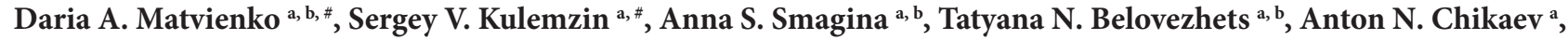 \\ Olga Y. Volkova a , Nikolay A. Chikaev ${ }^{a}$, Olga A. Koval ${ }^{\text {b, }}$, Elena V. Kuligina ${ }^{\text {b, c }}$, Alexandr V. Taranin ${ }^{\text {a, b}}$, \\ Andrey A. Gorchakov a, b \\ ${ }^{a}$ Institute of Molecular and Cellular Biology, Siberian Branch of the Russian Academy of Sciences, Novosibirsk, Russia \\ ${ }^{\mathrm{b}}$ Novosibirsk State University, Novosibirsk, Russia \\ ${ }^{c}$ Institute of Chemical Biology and Fundamental Medicine, Siberian Branch of the Russian Academy of Sciences, Novosibirsk, \\ Russia \\ \# equal contribution
}

Dr. Andrey A. Gorchakov, Institute of Molecular and Cellular Biology SB RAS, Lavrentyeva 8/2, Novosibirsk, 630090, Russia
Phone: $+7-383-363-90-72$

Fax: +7-383-363-90-64

E-mail: gorchakov@mcb.nsc.ru

\section{Summary}

Comprehensive structural optimization of chimeric antigen receptors (CARs) is the key to their successful performance both in vitro and in vivo. In order to compare various CAR designs in an unified format, we took advantage of a lentiviral platform, where all CAR modules can be easily shuffled and tested for functionality. This platform was used to delineate the effects of various spacer regions on the function of a PSCA-specific CAR in the context of a human NK cell line, YT. We show that three CAR designs (IgG1-, CD8a-, and spacerless) perform similarly in vitro regardless of the length of the spacer region.

\section{Keywords}

Chimeric antigen receptor (CAR), adoptive immunotherapy, prostate cancer, prostate stem cell antigen (PSCA).

\section{Introduction}

Worldwide, prostate cancer is known to be the third leading cause of cancer-associated deaths among elderly men. Whereas the survival rate for patients diagnosed with stage I-II prostate cancer approaches $85 \%$ due to impressive efficacy of surgery, chemotherapy, and radiotherapy, this is not the case for late-stage prostate cancer patients. As with many other cancers, prostate cancer typically remains unnoticed and asymptomatic at early stages, and about $90 \%$ of patients first present with stage III-IV prostate cancer, which is lethal in over 50\% cases [1]. Pancreatic cancer is also among the top most frequent causes of cancer-related deaths [2], with patients having few if any therapeutic options. Clearly, there is a pressing need for developing novel therapeutic modalities for metastatic prostate cancer and pancreatic cancer.

One of the cell surface protein molecules that has been reported to be overexpressed by both prostate and pancreatic tumors as well as metastases in a fraction of patients is PSCA (prostate stem cell antigen), a 123 aa-long GPI-anchored protein of largely unknown function and limited expression in normal tissues [3-6]. Targeting this cancer-associated marker therefore presents an attractive opportunity.

One of the recent advances in the field of cancer immunotherapy is based on the administration of cancer-specific $\mathrm{T}$ 
cells into the patients. In this approach, T cell retargeting is achieved via their ex vivo engineering with chimeric antigen receptors (CARs). Following adoptive transfer, CAR T cells specifically destroy malignant cells, proliferate and persist in vivo thereby mediating prolonged antitumor control.

CARs typically encompass four structural modules: i) antigen recognition module most frequently composed of an scFv; ii) spacer region, which provides adequate positioning of the antigen recognition module relatively to the target antigen as well as optimal spacing between contacting effector and target cells. This module is typically derived from CD8a, CD28, and IgG1/IgG4; iii) transmembrane domain, which helps anchor the CAR on the cell surface; and iv) intracellular signaling domain, which functions to activate the CAR-bearing effector cell upon encounter of the target cancer cell $[7,8]$. Two most common signaling domain designs tested in the clinical trials incorporate CD3 signaling domain in combination with either CD28 or 4-1BB co-stimulatory sequences [9]. Thus, CAR brings together the selectivity of antibodies and potent cytotoxicity of effector T cells. Yet, the design of clinically successful CARs still remains a trial-and-error process, and so multiple rounds of structural optimization may be required to produce clinically viable CAR T cell products.

Recently, two autologous CAR T cell based products targeting CD19 have been approved by FDA for treating pediatric patients with $\mathrm{r} / \mathrm{r}$ ALL and adults with $\mathrm{r} / \mathrm{r}$ large B-cell lymphoma, and many more CARs against other molecules and combinations thereof are currently in clinical trials [10, 11]. It is hoped that this success can be translated to solid cancers as well, however a combination of immunosuppressive tumor microenvironment, inefficient tumor homing, and limited CAR T cell persistence makes this goal a difficult feat [12]. In contrast to most B-cell malignancies, solid tumors share a hostile milieu encompassing various immune cells (M2 macrophages, Tregs, etc), endothelial cells, fibroblasts, extracellular matrix proteins, and inhibitory cytokines. This not only physically limits the access of CAR T cells to the tumor interior, but also has a potent immunosuppressive effect [13-15]. Several experimental approaches partially addressing these issues have been described in the literature, for instance CAR T cells have been designed to secrete additional molecules to attract resident immune cells or reverse the inhibitory effects of tumor-derived factors to boost $\mathrm{T}$ cell proliferation [16-23]. Alternative cell sources for CAR therapies have also been explored. In this regard, NK cells seem to be particularly promising, as they have long been known to be more efficient at tissue and tumor trafficking, as well as more resistant to immunosuppressive tumor microenvironment. Further, use of NK-cells in CAR therapies holds promise of their application as off-the-shelf allogeneic cell products [24-27]. Finally, combining CAR T cell therapies with other anticancer modalities, such as radiation therapy [28], chemotherapy [29], oncolytic virotherapy [30, 31], and small molecules and antibodies $[32,33]$ is also an area of active ongoing research.

Multiple studies have also focused on optimization of CAR structure to enhance activity of CAR T cells. When effector and tumor cells interact to form an immunologic syn- apse, the distance between the cell membranes lies within a fixed range and was reported to be critical for optimal CAR T cell-mediated cytotoxicity [34]. Hence, the choice of the spacer region in a CAR dictates the appropriate positioning of the antigen-recognition region and the cognate epitope, and should ideally be customized for each epitope/scFv pair to provide optimal in vitro and in vivo CAR T cell activity, particularly in the context of solid tumors.

In this study, we developed a series of CAR constructs targeting PSCA, which differ only in the spacer region used. These CARs were expressed in an NK cell line, YT, which we test as a platform for allogeneic CAR-NK cell therapy. CAR-NK cell lines obtained were comparatively assayed for in vitro cytotoxicity and IFN-g release. This, to our knowledge, is the first study to explore the contribution of the spacer region of a CAR in an NK-cell background.

\section{Materials and Methods}

\section{Cell lines and cell culture}

HEK293T and PC3 cells were purchased from ATCC (USA). YT cell line was kindly provided by Dr. A.V. Filatov. PSCA-expressing PC3 cells were produced via lentiviral transduction of a PSCA-encoding construct co-expressing tdTomato, followed by monocloning. All cell lines were cultured in IMDM (Sigma) supplemented with 4 mM L-glutamine, 10\% FCS (HyClone), $100 \mathrm{U} / \mathrm{ml}$ penicillin and $100 \mathrm{ug} / \mathrm{ml}$ streptomycin in $5 \% \mathrm{CO} 2$ at $37^{\circ} \mathrm{C}$. Cells were passaged every other day or one day before transfection/transduction.

\section{CAR design}

Antigen-recognition module of the PSCA-specific CAR was derived from the parental version of the $2 \mathrm{~B} 3$ antibody (humanized murine antibody) [35]. Coding sequence for $\mathrm{scFv}(2 \mathrm{~B} 3)$ flanked with AgeI and BamHI sites was obtained by gene synthesis (Genomatik) and inserted in-frame with the mIgk signal sequence and the c-myc epitope preceding hinge region (IgG1, CD8a, or none) of the pCDH-based lentiviral vectors described previously (GenBank acc. numbers KX757242.1, KX757244.1, KX757246.1) [36]. In these constructs, CAR expression was driven by a constitutive hybrid hEF1a-HTLV promoter.

\section{Assembly of VSV-G-pseudotyped lentiviral particles}

HEK293T cells were used for producing VSV-G- pseudotyped lentiviral particles. The cells were transfected following the standard Ca-phosphate transfection protocol [37]. DNA of lentiviral constructs was mixed with the DNA of packaging plasmids pMD.2G and psPAX2 [38] at a ratio of 4:1:3. Lentivirus-containing supernatants were collected 48 hours following transfection, filtered through $0.45-\mu \mathrm{m}$ PES filters and used either fresh or frozen at $-70^{\circ} \mathrm{C}$.

\section{Transduction of YT cells}

YT cells were transduced using spinoculation [39]. Briefly, YT cells were seeded into 96 -well plates $(1 \times 10[4]$ cells/well $)$ in the presence of polybrene $(8 \mathrm{ug} / \mathrm{ml})$, followed by addition of pseudotyped lentiviral particles. Non-transduced cells 
were kept as a control. Cells were centrifuged at $500 \mathrm{~g}$ for 40 minutes at $32^{\circ} \mathrm{C}$ and kept in the $\mathrm{CO} 2$ incubator for 16 hours. Next day, the supernatant was aspirated and replaced by the fresh culture medium.

\section{FACS profiling}

One hundred thousand cells were washed in PBS and incubated with mouse anti-c-myc (Abcam, clone 9E10) antibodies or protein L-bio (GenScript, M00097). PE-labeled donkey anti-mouse IgG conjugates (BioLegend) and SA-PE (Thermo Fisher Scientific) were used as secondary antibodies. 7AAD (Biolegend) was used to exclude dead cells from the analysis. The samples were analyzed using BD FACSCanto II instrument (Becton Dickinson and Company) and BD FACSDiva Software.

\section{Flow cytometry-based cytotoxicity assay and IFN-g release assay}

Target PC3(PSCA) or PC3 cells (T) were labeled with Cell Proliferation Dye eFluor 670 (eBioscience), washed, and incubated with CAR-expressing YT cells (E) at 1:1, 2:1, and 3:1 E:T ratios for 4 hours in round-bottom 96 wells TPP plates (\#92097, TPP). Then, the cells were stained with propidium iodide (PI) and analyzed by flow cytometry. Target cells left without effector cells were used as a negative control. The percentage of dead target cells (i.e. cytotoxicity) was calculated as follows: $100 \%$ * (PI+, eFluor +$)_{\text {count }} /(\text { total eFluor }+)_{\text {count' }}$, as described previously $[40,41]$.

In order to measure IFN-g release, aPSCA-CAR YT or non-transduced YT cells were incubated with target PC3(PSCA) or control PC3 cells at a 1:1 ratio in 24-well plates for 4 hours. Following incubation, cell culture supernatants were filtered through $0.45-\mu \mathrm{m}$ filters and IFN-g concentration in the supernatants was measured in duplicates using ELISA (IFA-best kit, Vektor-best, Russia).

\section{Results}

\section{Design of PSCA-specific CARs encompassing distinct spacer regions}

Three lentiviral constructs encoding second-generation PSCA-specific CARs were assembled using conventional cloning. Except for the spacer regions used, the structures of these CARs were identical as presented in Fig. 1. CopGFP reporter was used for labeling transduced effector cells, and c-myc epitope was placed downstream of the antigen-recognition module to conveniently detect CAR expression.

\section{PSCA-specific CARs are expressed on the surface of YT cells}

Human NK-cell lines such as NK-92, YT, KHYG-1, etc are an attractive cellular platform that may serve as a viable alternative to the autologous format of CAR T cell therapy [27, 42]. In our study, YT cell line [43] was selected as a carrier for CARs, as these cells are IL-2 independent and afford high transduction efficiency [41]. YT cells were transduced with lentiviral particles encoding three CAR variants described above and surface-stained with anti-myc antibodies to detect CAR expression (Fig. 2a). Pronounced CAR expression was detectable, yet spacerless CAR had an apparent reduction in surface expression. Given that viral titers used for transduction were very similar, we reasoned that this may have been caused by the proximity of c-myc epitope in this particular CAR variant to the cell membrane and its shielding from efficient recognition by anti-c-myc antibodies. This was indeed the case, as immunodetection of CARs using protein L, an immunoglobulin kappa-chain binder [44], confirmed consistent CAR expression in all three cases (Fig. 2b).

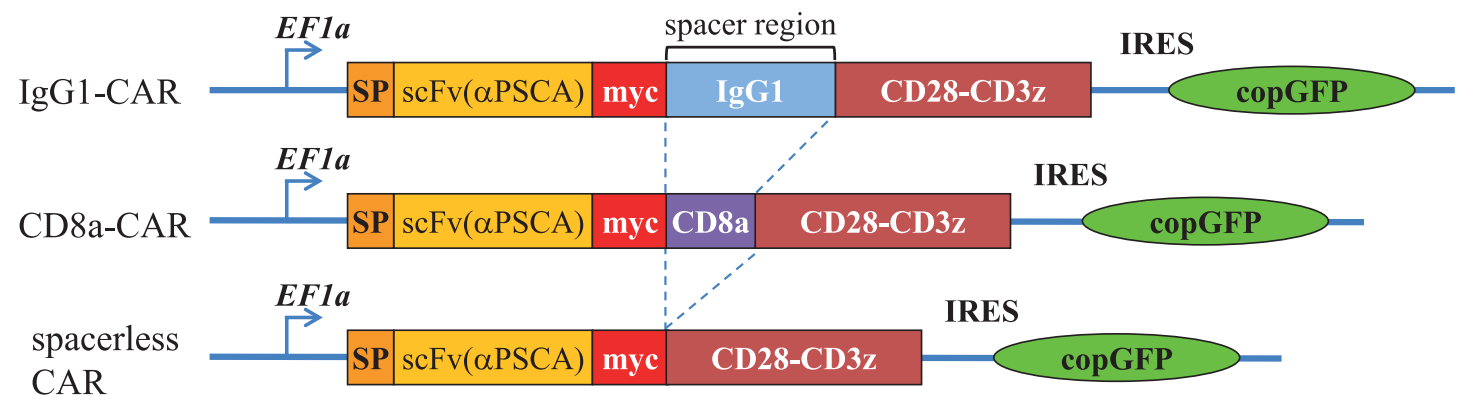

Figure 1. Structure of the CAR-encoding lentiviral constructs. EFla - constitutive hEFla-HTLV promoter, SP - leader sequence of murine Igk, scFv(aPSCA) - antigen-recognition module derived from the humanized PSCA-specific antibody 2B3, CD8a and IgGl - spacer modules derived from human CD8a and IgGl, CD28-CD3cyto - transmembrane and intracellular signaling region, IRES - internal ribosome entry site of cardiovirus A, copGFP - GFP from a copepod Pontellina plumata 
A

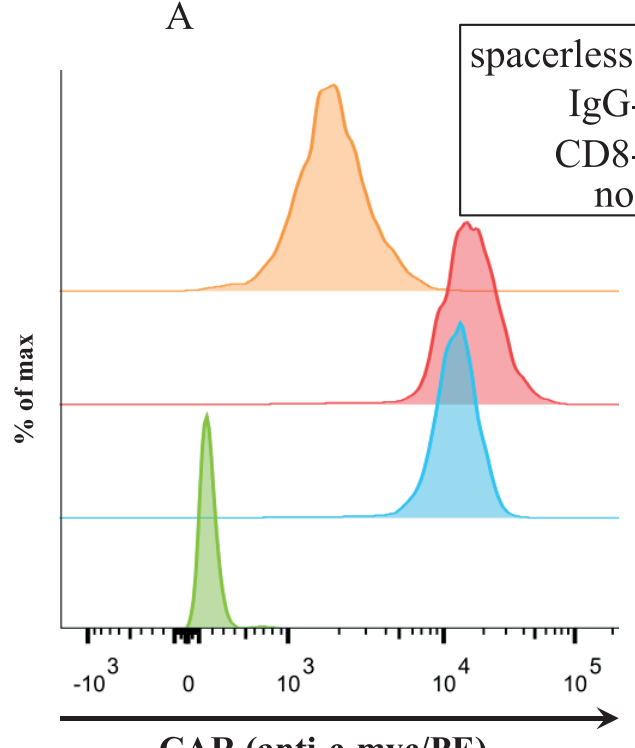

CAR (anti-c-myc/PE)
$\mathrm{B}$

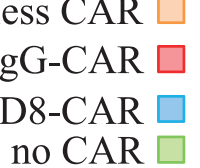

(1)

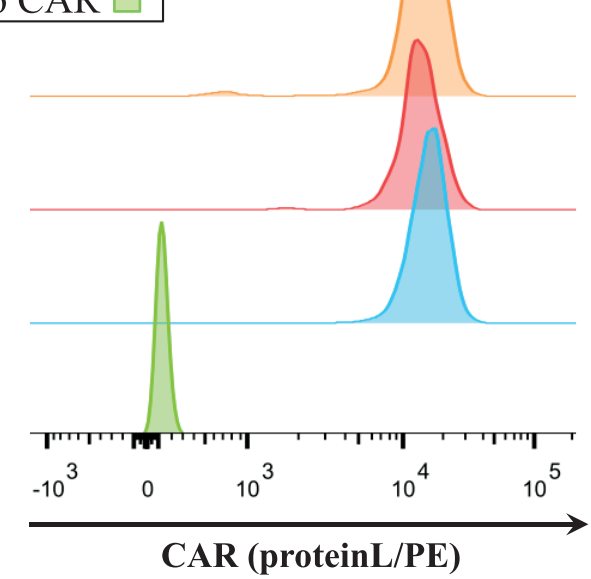

Figure 2. Surface expression of CARs in the context of YT cells. A. anti-c-myc staining; B. protein L staining

\section{CAR-YT cells display specific cytotoxicity against target cells and secrete IFN-g in vitro}

Whether or not CAR-YT cells display PSCA-specific cytotoxicity, was tested using a FACS-based assay. Following incubation with PSCA-expressing target cells (PC3-PSCA) but not with isogenic PSCA-negative controls (PC3), CARYT cells displayed $25 \%$ killing of target cells within the E:T ratios tested (Fig. 3a). This was observed for all three CAR designs regardless of the spacer region used. Next, we proceeded to analyze whether this was accompanied by IFN-g release. Upon co-incubation with target PC3-PSCA cells, we observed pronounced IFN-g secretion, and again it was overall comparable in all the CAR-YT cell lines obtained (Fig. 3b).

\section{Discussion}

To date, multiple PSCA-specific CARs have been created and validated both in vitro and in vivo. These CARs encompass various antigen-binding regions (derived from $\mathrm{mAbs}$ 1G8, 7F5, bm2B3, Ha1-4.117, etc), spacers (IgG4, IgG1, IgD, $\mathrm{CH} 3$, spacerless, CD8a), as well as signaling domains (CD3z, CD28-CD3z, CD28-4-1BB-CD3z, CD28-OX40-CD3z, and DAP12), and were expressed in primary human T cells, NK cells, and NK cell lines [6, 45-51]. Whenever the studies were structure-oriented and comparative by design, minor modifications in CAR architecture resulted in profound changes in CAR performance. However, to our knowledge, none of the above studies addressed the question whether the spacer region of PSCA-specific CARs should be tailored to the context of immunological synapse of NK-cells.

In our study, we asked whether PSCA-specific CARs may require structural optimization of the spacer region when expressed by NK-cells rather than conventional T cells. This optimization was reported to be necessary for adequate CAR performance in vitro and particularly in vivo in the context of primary T cells $[50,52]$. In our in vitro assays, PSCA-specific CARs encompassing either long IgG1, short CD8a, or no spacer region behaved very similar. Whether this may apply to other in vitro tests and in vivo situation, remains to be explored.

PSCA is a relatively small protein, accordingly the epitope recognized by our CARs is found in a membrane-proximal position relatively to the tumor cell surface. Thus, the contribution of the length and flexibility of the spacer region of a CAR may have less of an effect on the sterical compatibility of the CAR and the target epitope, which may partially explain our in vitro results. The observed lack of effect of spacer region on CAR-NK cell functionality is unlike what was observed for PSCA-specific CAR T cells [50, 52]. We speculate that this may be attributable to some yet unknown peculiarities of immune synapse formation between CARNK and tumor cells.

In conclusion, the different PSCA-specific CAR designs assayed in the context of YT cells appear functional in vitro and may serve as a platform for developing allogeneic CARNK cell products for cell therapy of patients with PSCA-positive prostate and pancreatic tumors.

\section{Acknowledgements}

This work was supported by the Ministry of Education and Science of the Russian Federation, grant agreement № 14.604.21.0169 (unique project identifier RFMEFI60417X0169). The authors gratefully acknowledge the resources provided by the "Molecular and Cellular Biology" core facility of the IMCB SB RAS and the Collective Center for microscopic analysis of biological objects of the SB RAS. 

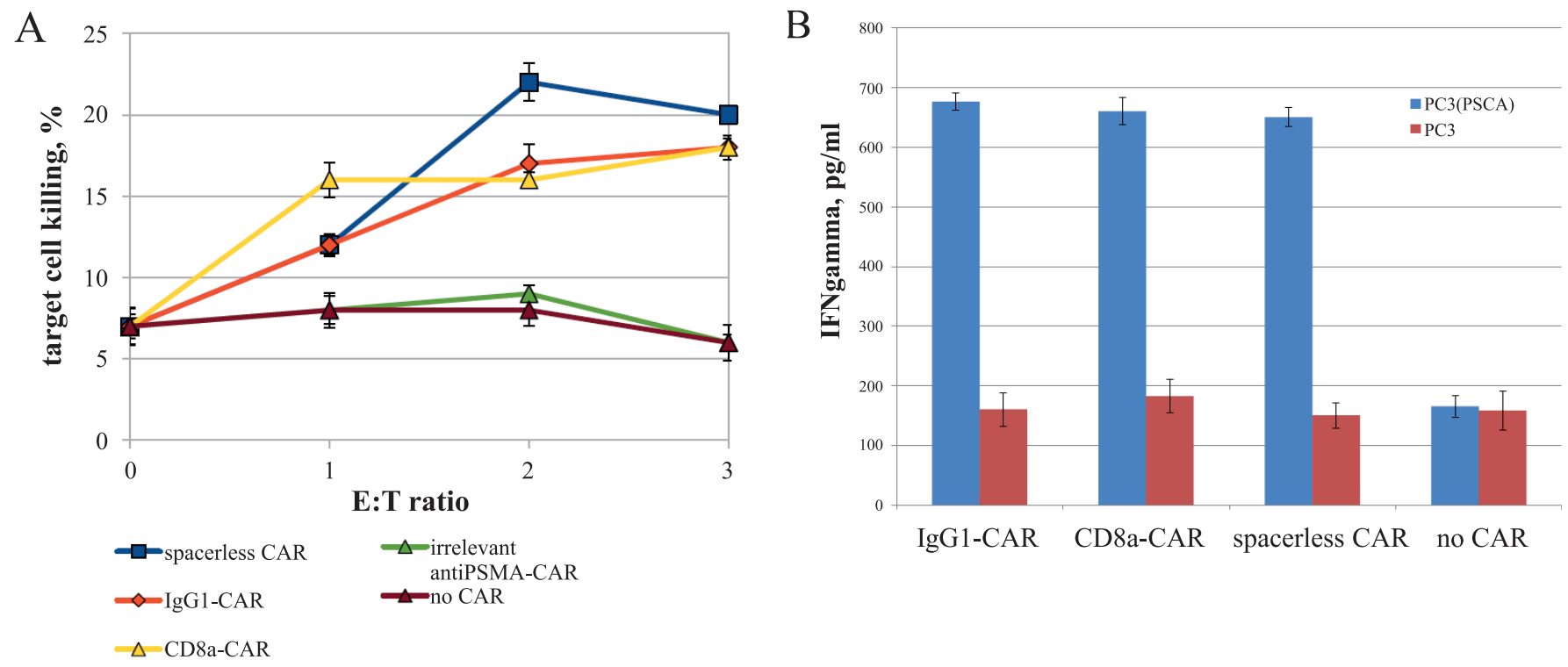

Figure 3. A. CAR-YT cells are retargeted against PSCA-expressing prostate cancer cells and spare PSCA-negative isogenic controls at E:T ratios ranging from 1 to 3 regardless of the structure of the spacer region of the CAR. Irrelevant CAR-YT cells specific for PSMA fail to kill PSCA-expressing cells. Average percentage $+/$ - standard deviation values from two technical replicas are plotted. B. CAR-YT cells secrete IFN-g upon co-incubation with cognate target cells

\section{Conflict of interest}

No conflict of interests is reported by the authors.

\section{References}

1. Miller KD, Siegel RL, Lin CC, Mariotto AB, Kramer JL, Rowland JH, Stein KD, Alteri R, Jemal A. Cancer treatment and survivorship statistics. 2016. CA Cancer J Clin. 2016; 66(4):271-289.

2. Siegel RL, Miller KD, Jemal A. Cancer Statistics. 2017. CA Cancer J Clin. 2017; 67(1):7-30.

3. Reiter RE, Gu Z, Watabe T, Thomas G, Szigeti K, Davis E, Wahl M, Nisitani S, Yamashiro J, Le Beau MM, Loda M, Witte ON. Prostate stem cell antigen: a cell surface marker overexpressed in prostate cancer. Proc Natl Acad Sci U S A. 1998; 95(4):1735-1740.

4. Gu Z, Thomas G, Yamashiro J, Shintaku IP, Dorey F, Raitano A, Witte ON, Said JW, Loda M, Reiter RE. Prostate stem cell antigen (PSCA) expression increases with high gleason score, advanced stage and bone metastasis in prostate cancer. Oncogene. 2000; 19(10):1288-1296.

5. Argani P, Rosty C, Reiter RE, Wilentz RE, Murugesan SR, Leach SD, Ryu B, Skinner HG, Goggins M, Jaffee EM, Yeo CJ, Cameron JL, Kern SE, Hruban RH. Discovery of new markers of cancer through serial analysis of gene expression: prostate stem cell antigen is overexpressed in pancreatic adenocarcinoma. Cancer Res. 2001; 61(11):4320-4324.

6. Katari UL, Keirnan JM, Worth AC, Hodges SE, Leen AM, Fisher WE, Vera JF. Engineered T cells for pancreatic cancer treatment. HPB (Oxford). 2011; 13(9):643-650.
7. Dotti G, Gottschalk S, Savoldo B, Brenner MK. Design and development of therapies using chimeric antigen receptor-expressing T cells. Immunol Rev. 2014; 257(1):107-126.

8. Kulemzin SV, Kuznetsova VV, Mamonkin M, Taranin AV, Gorchakov AA. Engineering Chimeric Antigen Receptors. Acta Naturae. 2017a; 9(1):6-14.

9. Maus MV, Fraietta JA, Levine BL, Kalos M, Zhao Y, June $\mathrm{CH}$. Adoptive immunotherapy for cancer or viruses. Annu Rev Immunol. 2014; 32:189-225.

10. Ormhøj M, Bedoya F, Frigault MJ, Maus MV. CARs in the lead against multiple myeloma. Curr Hematol Malig Rep. 2017; 12(2):119-125.

11. Maude SL, Laetsch TW, Buechner J, Rives S, Boyer M, Bittencourt H, Bader P, Verneris MR, Stefanski HE, Myers GD, Qayed M, De Moerloose B, Hiramatsu H, Schlis K, Davis KL, Martin PL, Nemecek ER, Yanik GA, Peters C, Baruchel A, Boissel N, Mechinaud F, Balduzzi A, Krueger J, June CH, Levine BL, Wood P, Taran T, Leung M, Mueller KT, Zhang Y, Sen K, Lebwohl D, Pulsipher MA, Grupp SA. Tisagenlecleucel in children and young adults with B-cell lymphoblastic leukemia. N Engl J Med. 2018; 378(5):439-448.

12. Beatty GL, O'Hara M. Chimeric antigen receptor-modified $\mathrm{T}$ cells for the treatment of solid tumors: Defining the challenges and next steps. Pharmacol Ther. 2016; 166:30-39.

13. Gilham DE, Debets R, Pule M, Hawkins RE, Abken H. CAR-T cells and solid tumors: tuning $\mathrm{T}$ cells to challenge an inveterate foe. Trends Mol Med. 2012; 18(7):377-384.

14. Kakarla S, Gottschalk S. CAR T cells for solid tumors: armed and teady to go? Cancer J. 2015; 20(2):151-155. 
15. Zhang H, Ye ZL, Yuan ZG, Luo ZQ, Jin HJ, Qian QJ. New strategies for the treatment of solid tumors with CAR-T cells. Int J Biol Sci. 2016; 12(6):718-729.

16. Chmielewski M, Kopecky C, Hombach AA, Abken H. IL-12 release by engineered T cells expressing chimeric antigen receptors can effectively muster an antigen-independent macrophage response on tumor cells that have shut down tumor antigen expression. Cancer Res. 2011; 71(17):56975706.

17. Chmielewski M, Abken H. CAR T cells transform to trucks: chimeric antigen receptor-redirected $\mathrm{T}$ cells engineered to deliver inducible IL-12 modulate the tumour stroma to combat cancer. Cancer Immunol Immunother. 2012; 61(8):1269-1277.

18. Cherkassky L, Morello A, Villena-Vargas J, Feng Y, Dimitrov DS, Jones DR, Sadelain M, Adusumilli PS. Human CAR T cells with cell-intrinsic PD-1 checkpoint blockade resist tumor-mediated inhibition. J Clin Invest. 2016; 126(8):31303144 .

19. Liu X, Ranganathan R, Jiang S, Fang C, Sun J, Kim S, Newick K, Lo A, June CH, Zhao Y, Moon EK. A chimeric switch-receptor targeting PD1 augments the efficacy of second-generation CAR T cells in advanced solid tumors. Cancer Res. 2016; 76(6):1578-1590.

20. Chmielewski M, Abken H. CAR T cells releasing IL-18 convert to T-Bethigh FoxOllow effectors that exhibit augmented activity against advanced solid tumors. Cell Rep. 2017; 21(11):3205-3219.

21. Mohammed S, Sukumaran S, Bajgain P, Watanabe N, Heslop HE, Rooney CM, Brenner MK3, Fisher WE, Leen AM, Vera JF. Improving Chimeric Antigen Receptor-modified $\mathrm{T}$ cell function by reversing the immunosuppressive tumor microenvironment of pancreatic cancer. Mol Ther. 2017; 25(1):249-258

22. Kloss CC, Lee J, Zhang A, Chen F, Melenhorst JJ, Lacey SF, Maus MV, Fraietta JA, Zhao Y, June CH. Dominant-negative TGF- $\beta$ receptor enhances PSMA-targeted human CAR $\mathrm{T}$ cell proliferation and augments prostate cancer eradication. Mol Ther. 2018; S1525-0016(18)30206-5.

23. Sukumaran S, Watanabe N, Bajgain P, Raja K, Mohammed S, Fisher WE, Brenner MK, Leen AM, Vera JF. Enhancing the potency and specificity of engineered T cells for cancer treatment. Cancer Discov. 2018; CD-17-1298.

24. Giannattasio A, Weil S, Kloess S, Ansari N, Stelzer EH, Cerwenka A, Steinle A, Koehl U, Koch J. Cytotoxicity and infiltration of human NK cells in in vivo-like tumor spheroids. BMC Cancer. 2015; 15:351.

25. Glienke W, Esser R, Priesner C, Suerth JD, Schambach A, Wels WS, Grez M, Kloess S, Arseniev L, Koehl U. Advantages and applications of CAR-expressing natural killer cells. Front Pharmacol. 2015; 6:21.

26. Hermanson DL, Kaufman DS. Utilizing chimeric antigen receptors to direct natural killer cell activity. Front Immunol. 2015; 6:195.
27. Mehta RS, Rezvani K. Chimeric antigen receptor expressing natural killer cells for the immunotherapy of cancer. Front Immunol. 2018; 9:283.

28. Weiss T, Weller M, Guckenberger M, Sentman CL, Roth P. NKG2D-Based CAR T cells and radiotherapy exert synergistic efficacy in glioblastoma. Cancer Res. 2018 Feb 15; 78(4):1031-1043.

29. Sanchez C, Chan R, Bajgain P, Rambally S, Palapattu G, Mims M, Rooney CM, Leen AM, Brenner MK, Vera JF. Combining T-cell immunotherapy and anti-androgen therapy for prostate cancer. Prostate Cancer Prostatic Dis. 2013; 16(2):123-131, S1.

30. Nishio N, Diaconu I, Liu H, Cerullo V, Caruana I, Hoyos V, Bouchier-Hayes L, Savoldo B, Dotti G. Armed oncolytic virus enhances immune functions of chimeric antigen receptor-modified T cells in solid tumors. Cancer Res. 2014; 74(18):5195-5205.

31. Rosewell Shaw A, Porter CE, Watanabe N, Tanoue K, Sikora A, Gottschalk S, Brenner MK, Suzuki M. Adenovirotherapy delivering cytokine and checkpoint inhibitor augments CAR T cells against metastatic head and neck cancer. Mol Ther. 2017; 25(11):2440-2451.

32. Kobold S, Steffen J, Chaloupka M, Grassmann S, Henkel J, Castoldi R, Zeng Y, Chmielewski M, Schmollinger JC, Schnurr M, Rothenfußer S, Schendel DJ, Abken H, Sustmann C, Niederfellner G, Klein C, Bourquin C, Endres S. Selective bispecific $\mathrm{T}$ cell recruiting antibody and antitumor activity of adoptive T cell transfer. J Natl Cancer Inst. 2014; 107(1):364.

33. Jetani H, Garcia-Cadenas I, Nerreter T, Thomas S, Rydzek J, Meijide JB, Bonig H, Herr W, Sierra J, Einsele H, Hudecek M. CAR T-cells targeting FLT3 have potent activity against FLT3-ITD+ AML and act synergistically with the FLT3-inhibitor crenolanib. Leukemia. 2018; 32(5):1168-1179.

34. Mukherjee M, Mace EM, Carisey AF, Ahmed N, Orange JS. Quantitative imaging approaches to study the CAR immunological synapse. Mol Ther. 2017; 25(8):1757-1768.

35. Olafsen T, Gu Z, Sherman MA, Leyton JV, Witkosky ME, Shively JE, Raubitschek AA, Morrison SL, Wu AM, Reiter RE. Targeting, imaging, and therapy using a humanized antiprostate stem cell antigen (PSCA) antibody. J Immunother. 2007; 30(4):396-405.

36. Kulemzin SV, Chikaev NA, Volkova OY, Kuznetsova VV, Taranin AV. Gorchakov AA. Modular lentiviral vector system for chimeric antigen receptor design optimization. Bioorg Khim. 2017b; 43(2):124-132 (In Russian).

37. Kutner RH, Zhang XY, Reiser J. Production, concentration and titration of pseudotyped HIV-1-based lentiviral vectors. Nat Protoc. 2009; 4(4):495-505.

38. Zufferey R, Nagy D, Mandel RJ, Naldini L, Trono D. Multiply attenuated lentiviral vector achieves efficient gene delivery in vivo. Nat Biotechnol. 1997; 15(9):871-875.

39. O’Doherty U, Swiggard WJ, Malim MH. Human immunodeficiency virus type 1 spinoculation enhances infection through virus binding. J Virol. 2000; 74:10074-10080. 
40. Lecoeur H, Février M, Garcia S, Rivière Y, Gougeon ML. A novel flow cytometric assay for quantitation and multiparametric characterization of cell-mediated cytotoxicity. J Immunol Methods. 2001; 253(1-2):177-187.

41. Kulemzin SV, Gorchakov AA, Chikaev AN, Kuznetsova VV, Volkova OY, Matvienko DA, Petukhov AV, Zaritskey AY, Taranin AV. VEGFR2-specific FnCAR effectively redirects the cytotoxic activity of T cells and YT NK cells. Oncotarget. 2018; 9(10):9021-9029.

42. Suck G, Odendahl M, Nowakowska P, Seidl C, Wels WS, Klingemann HG, Tonn T. NK-92: an 'off-the-shelf therapeutic' for adoptive natural killer cell-based cancer immunotherapy. Cancer Immunol Immunother. 2016; 65(4):485-492.

43. Yodoi J, Teshigawara K, Nikaido T, Fukui K, Noma T, Honjo T, Takigawa M, Sasaki M, Minato N, Tsudo M. TCGF (IL 2)-receptor inducing factor(s). I. Regulation of IL 2 receptor on a natural killer-like cell line (YT cells) J Immunol. $1985 ; 134: 1623-1630$.

44. Zheng Z, Chinnasamy N, Morgan RA. Protein L: a novel reagent for the detection of chimeric antigen receptor (CAR) expression by flow cytometry. J Transl Med. 2012; 10:29.

45. Kloss CC, Condomines M, Cartellieri M, Bachmann M, Sadelain M. Combinatorial antigen recognition with balanced signaling promotes selective tumor eradication by engineered T cells. Nat Biotechnol. 2013; 31(1):71-75.

46. Abate-Daga D, Lagisetty KH, Tran E, Zheng Z, Gattinoni L, Yu Z, Burns WR, Miermont AM, Teper Y, Rudloff U, Restifo NP, Feldman SA, Rosenberg SA, Morgan RA. A novel chimeric antigen receptor against prostate stem cell antigen mediates tumor destruction in a humanized mouse model of pancreatic cancer. Hum Gene Ther. 2014; 25(12):1003-1012.

47. Hillerdal V, Ramachandran M, Leja J, Essand M. Systemic treatment with CAR-engineered T cells against PSCA delays subcutaneous tumor growth and prolongs survival of mice. BMC Cancer. 2014; 14:30.
48. Töpfer K, Cartellieri M, Michen S, Wiedemuth R, Müller N, Lindemann D, Bachmann M, Füssel M, Schackert G, Temme A. DAP12-based activating chimeric antigen receptor for NK cell tumor immunotherapy. J Immunol. 2015; 194(7):3201-3212.

49. Priceman SJ, Gerdts EA, Tilakawardane D, Kennewick KT, Murad JP, Park AK, Jeang B, Yamaguchi Y, Yang X, Urak R, Weng L, Chang WC, Wright S, Pal S, Reiter RE, Wu AM, Brown CE, Forman SJ. Co-stimulatory signaling determines tumor antigen sensitivity and persistence of CAR T cells targeting PSCA+ metastatic prostate cancer. Oncoimmunology. 2017; 7(2):e1380764.

50. Qin L, Lai Y, Zhao R, Wei X, Weng J, Lai P, Li B, Lin S, Wang S, Wu Q, Liang Q, Li Y, Zhang X, Wu Y, Liu P, Yao Y, Pei D2, Du X, Li P. Incorporation of a hinge domain improves the expansion of chimeric antigen receptor $\mathrm{T}$ cells. J Hematol Oncol. 2017; 10(1):68.

51. Wei X, Lai Y, Li J, Qin L, Xu Y, Zhao R, Li B, Lin S, Wang S, Wu Q, Liang Q, Peng M, Yu F, Li Y, Zhang X, Wu Y, Liu P, Pei D, Yao Y, Li P. PSCA and MUC1 in non-small-cell lung cancer as targets of chimeric antigen receptor T cells. Oncoimmunology. 2017; 6(3):e1284722.

52. Watanabe N, Bajgain P, Sukumaran S, Ansari S, Heslop HE, Rooney CM, Brenner MK, Leen AM, Vera JF. Fine-tuning the CAR spacer improves T-cell potency. Oncoimmunology. 2016; 5(12):e1253656. 


\section{Анализ цитотоксической активности NK-клеточных линий, экспрессирующих PSCA-специфичные химер- ные антигенные рецепторы различной структуры}

Дарья А. Матвиенко а, b,, Сергей В. Кулемзин ${ }^{\text {a, \#, Анна С. Смагина }}{ }^{\text {a, b }}$, Татьяна Н. Беловежец ${ }^{\text {a, b }}$, Антон Н. Чикаев ${ }^{\text {a }}$ Ольга Ю. Волкова ${ }^{a}$, Николай А. Чикаев ${ }^{a}$, Ольга А. Коваль ${ }^{\text {b, }}$, Елена В. Кулигина ${ }^{\text {b, }}$, Александр В. Таранин ${ }^{\text {a b }}$, Андрей А. Горчаков ${ }^{\text {a, }}$

a Институт молекулярной и клеточной биологии СО РАН, Новосибирск

b Новосибирский государственный университет, Новосибирск

' Институт химической биологии и фундаментальной медицины СО РАН, Новосибирск

\# Оба автора внесли равный вклад в данную работу

\section{Резюме}

Структурная оптимизация модульного состава химерных антигенных рецепторов (CAR) может иметь принципиальное значение для обеспечения активности CAR T-клеточных продуктов. Мы воспользовались разработанной ранее платформой лентивирусных векторов для сравнения различных вариантов дизайна CAR в унифицированном формате. В частности, было проведено исследование влияния шарнирного района на функционирование PSCA-специфичного CAR в контексте NK-клеточной линии ҮТ. Было обнаружено, что независимо от природы и наличия шарнирного района (IgG1, CD8a и без шарнира) все три CAR обнаруживают сравнимые уровни активности in vitro.

\section{Ключевые слова}

Химерный антигенный рецептор (CAR), адоптивная иммунотерапия, рак простаты, антиген стволовых клеток простаты (PSCA). 